\title{
The Canning of Green Bananas. III. Effect of Storage and Processing Variables on Chemical Composition, Texture ${ }^{1}$ and Sensory Attributes
}

\author{
F. Sanchez-Nieva and M. Mercado ${ }^{2}$ \\ ABSTRACT
}

The following changes were observed in canned acidified green bananas during storage at $85^{\circ} \mathrm{F}\left(29.4^{\circ} \mathrm{C}\right)$ : The stabilization $\mathrm{pH}$ and the fruit $\mathrm{pH}$ and acidity suffered no appreciable change; a pink discoloration developed resulting in an increase in Hunter a value and a decrease in $\boldsymbol{b}$. No change in total and reducing sugars took place. The product hardened during storage with an increase in shear press values. Organoleptic qualities suffered no significant changes during storage. The following processing factors affected the texture of the canned bananas: length of the hot water peeling treatment and temperature of the bath, length of the thermal treatment of the product in boiling water, stage of development of the fruit processed, and storage temperature. Storage of the product at $45^{\circ} \mathrm{F}\left(7.2^{\circ} \mathrm{C}\right)$ resulted in a pronounced hardening of the canned bananas.

\section{INTRODUCTION}

In the preceeding paper of this series (II) it was indicated that the short shelf life of the canned acidified green bananas was due to the rapid detinning of the tin containers and to the development of a strong dark discoloration when the product was canned in enamel containers.

Even though most of the lots processed could not be studied for a period longer than 3 or 4 months, a few lots, possibly because the bananas processed were low in nitrates, kept fairly well in storage at ambient temperature $\left(85^{\circ} \mathrm{F}\right.$ av., $24.4^{\circ} \mathrm{C}$ ) for nearly a year. The study of the different factors affecting the characteristics of these lots during processing and storage gives at least an insight into the behavior that might be expected if green bananas can eventually be packed in an inert container like glass.

\section{MATERIALS AND METHODS}

Green fruit of the Montecristo cultivar was used in this study. The canned samples for shelf life studies were prepared from fruit purchased from a local ripening plant. The fruit used in studies to determine the effect of stage of development on different quality attributes was obtained from an experimental plot of 200 plants of the Montecristo cultivar

${ }^{1}$ Manuscript submitted to Editorial Board December 2, 1981.

${ }^{2}$ Chemical Engineer (retired); and Production Manager, NUMAR, Inc., Aguadilla, P. R., formerly Research Assistant, respectively, Food Technology Laboratory, Agricultural Experiment Station, Mayagüez Campus, University of Puerto Rico, Río Piedras, P. R. Mrs. I. Caloni of the Food Technology Laboratory of the Aricultural Experiment Station for prepared the "guineos en escabeche" samples and conducted the sensory tests. 
established at the Corozal Substation. The procedures followed in the production and harvesting of the fruit from this plot were described by Sánchez Nieva et al. (8).

Canned samples were prepared and processed as described by Sánchez and Mercado (10).

$\mathrm{pH}$ and acidity of fresh fruit was determined by A.O.A.C. methods. Stabilization $\mathrm{pH}$ and acidity of canned samples as well as $\mathrm{pH}$ and acidity of the fruit solids and brine were determined according to standard procedures for acidified canned products (1).

Moisture was determined by A.O.A.C. method (3). Total and reducing sugars were determined by the method of Moyer and Holgate (2). Ascorbic acid was determined by the 2-6 dichlorophenal indophenol method (3).

Color was measured on the interior and exterior surfaces of drained canned fruit or in fruit before canning with a Hunter lab Model D color difference meter ${ }^{3}$ calibrated with a yellow standard (Hunterlab Std. no. 3127: $L=78.2, a=4.1, b=30.8$ ). For measuring the color of the exterior surface the fruit sections were placed on their sides in the measuring cell. For measuring the color of the interior surface, the slices were cut in halves and the halves placed with the cut surface down in the cell. For all measurements the cell was covered with a Kodak Neutral Test Card, white side down.

The turbidity of the packing media was measured as follows: A sample of the brine was diluted 1:1 with distilled water. The transmittance of a $10 \mathrm{ml}$ sample was read in the Klett-Summerson colorimeter with a No. 47 blue filter. Turbidity measurements are expressed in the instrument scale units.

For texture measurements a Food Technology Corporation shear press was used as described by Sánchez Nieva and Mercado (7). The fruit was drained in a No. 8 standard sieve and then weighed for texture measurements.

For organoleptic evaluation, the canned green bananas were used to prepare a local dish known as "guineos en escabeche." This dish consists of a marinating sauce in which the green boiled bananas are dipped. The marinating sauce was prepared according to the following recipe: $4 \mathrm{lb}$. onions, 1 fresh garlic clove, 3 bay leaves, 1 teaspoon black pepper, 1.5 teaspoon salt, 2.5 cups cider vinegar and $1 / 2$ gallon olive oil. After mixing all the ingredients the sauce was simmered in a saucepan for 30 minutes.

The canned bananas were drained, boiled in water for 15 minutes, and

\footnotetext{
${ }^{3}$ Trade names in this publication are used only to provide specific information. Mention of a trade name does not constitute a warranty of equipment or materials by the Agricultural Experiment Station of the University of Puerto Rico, nor is this mention a statement of preference over other materials.
} 
drained again; the banana sections were put in the marinating sauce and left standing at room temperture for 24 hours before being tasted.

As a reference sample, "guineos en escabeche" were prepared from fresh bananas using the same marinating sauce. The fruit was peeled by hand and boiled in salt water for 25 minutes. The fruit was put in the sauce and boiled 10 minutes, cooled to room temperature and left standing for 24 hours before being tasted.

For organoleptic tests, each sample was rated separately for appearance, flavor, off-flavor intensity, texture and overall sample quality. With the exception of texture, the other quality attributes were rated on a 6point scale. Texture was rated with descriptive terms raging from soft to hard with normal texture in the middle of the scale, which ranged from 1 for soft to 9 for hard, normal texture being given a score of 5 . Samples were rated by a group of 9 to 10 tasters under fluorescent room lighting.

\section{RESULTS AND DISCUSSION}

The change in $\mathrm{pH}$ during storage in two lots studied, as previously reported (10) was negligible. Table 1 shows neither significant changes in the acidity of the whole can content nor in the acidified fruit.

Table 2 shows changes in some physical and chemical attributes during storage. No significant changes in total and reducing sugars took place during the storage for 270 days. An increase in ascorbic acid was observed, which may have been due to the formation of reducing substances which interfere in the determination of the vitamin. No changes in drained weight were noted.

With regard to the color of the fruit, $L$ values remained fairly constant during storage; $a$ values shifted to the positive side indicating an increase in redness. A slight decrease in $b$ values was observed. Brine turbidities increased during storage.

Sánchez Nieva and Mercado (9) showed that the color of hot-water peeled green bananas changed with the pulp to peel ratio, the yellowness increasing as the ratio increased. This change in color with maturity had a pronounced effect on the quality of the frozen bananas. In the canned product, the color of the fruit was also found to be related to the stage of maturity. The following changes in Hunter color values were observed as the pulp to peel ratio increased. When the color was measured on the sides of the fruit $L$ values decreased, $a$ values increased, indicating an increase in redness; and $b$ values increased, indicating an increase in yellowness, which was to be expected on the basis of the results of previous studies (9).

Visual inspection of the canned fruit showed that a light redish color developed during storage at ambient temperature, which resulted in the increase in $a$ values. Ranganna and Parpia $(4,5)$ reported that the 
development of a pink discoloration in canned bananas was due to reactions of the leucoanthocyanidines during heating.

It was not possible to submit the acidified canned bananas as such to sensory appraisal since the tasters objected to the high acidity of the product. To overcome this difficulty the product was used to prepare "guineitos en escabeche." As a reference sample an "escabeche" was prepared from fresh bananas each time the canned lots were tasted. Table 3 shows results of these tests.

TABLE 1.-Changes in $\mathrm{pH}$ and acidity during storage at $85-90^{\circ} \mathrm{F}\left(29.4-32.2^{\circ} \mathrm{C}\right)$

\begin{tabular}{ccccc}
\hline \multirow{2}{*}{ Time of storage } & \multicolumn{2}{c}{$\mathrm{pH}$} & \multicolumn{2}{c}{ Acidity } \\
\cline { 2 - 5 } & Stabilization & Fruit & Stabilization & Fruit \\
\hline Days & & & $\%$ & $\%$ \\
3 & 3.85 & 4.06 & 0.29 & 0.27 \\
16 & 3.90 & 4.02 & .30 & .29 \\
90 & 4.21 & 4.19 & .36 & .36 \\
185 & 3.93 & 4.03 & .31 & .20 \\
264 & 3.95 & 3.98 & .29 & .28 \\
365 & 4.05 & 4.10 & - & - \\
\hline
\end{tabular}

TABLE 2.-Changes in some chemical and physical properties of acidified canned green bananas during storage at $85-90^{\circ} \mathrm{F}\left(29.4-32.2^{\circ} \mathrm{C}\right)$

\begin{tabular}{|c|c|c|c|c|c|c|c|c|}
\hline \multirow{2}{*}{$\begin{array}{c}\text { Item } \\
\text { Time of storage - days }\end{array}$} & \multicolumn{4}{|c|}{ Sample 1} & \multicolumn{4}{|c|}{ Sample 2} \\
\hline & 16 & 98 & 184 & 270 & 28 & 97 & 171 & 276 \\
\hline Moisture-\% & 74.7 & 74.4 & 75.7 & 74.7 & 73.5 & 72.8 & 75.8 & 76.0 \\
\hline Total sugars-\% & 1.1 & 1.2 & 1.0 & 1.0 & - & - & - & - \\
\hline Reducing sugars-\% & 0.9 & 0.9 & 0.8 & 0.9 & 0.2 & 0.1 & 0.1 & 0.2 \\
\hline Ascorbic acid — mg/100g & 6.3 & 5.3 & 6.3 & 9.8 & 5.3 & 6.3 & 8.9 & 8.1 \\
\hline Color of fruit $L$ & 70.3 & 72.0 & 73.1 & 71.0 & 70.6 & 71.8 & 70.3 & 70.6 \\
\hline$a$ & -1.6 & -0.7 & 0.2 & 1.7 & -0.2 & 0.5 & 1.4 & 2.1 \\
\hline$b$ & 20.8 & 19.4 & 19.2 & 19.0 & 24.3 & 20.9 & 20.6 & 19.5 \\
\hline $\begin{array}{l}\text { Brine turbidity-Klett- } \\
\text { Summerson units }\end{array}$ & 116.0 & 165.0 & 141.0 & 166.0 & 136.0 & 117.0 & 139.0 & 148.0 \\
\hline
\end{tabular}

The results of the organoleptic test must be interpreted with the recognition that the evaluation of the product as "escabeche" and the use of an "escabeche" prepared from fresh banana as a reference sample impose certain constraints in the true evaluation of the sensory attributes and shelf life of the product.

Although the recipe for the preparation of the "escabeche" was standardized, variations in cooking procedures which are unavoidable may lead to changes in the organoleptic properties. The use of a fresh sample as reference sample provides the means of comparing the quality of the product prepared from the canned fruit with that prepared by the 
housewife from fresh bananas, but since the fruit used to prepare the fresh product was purchased from the fresh market at different intervals throughout the year, variations in color and other quality attributes resulted in unavoidable variations in the reference samples.

The data in table 3 allows for two types of analyses: 1) the comparison of the quality of the canned product, with a fresh sample at each test interval and 2) variations in the different quality attributes during storage.

Table 3 shows that in all three tests conducted after storage of the canned product for about a month, 5 months and 11 months, respectively, the "escabeche" prepared from the canned bananas was rated generally higher than the reference samples. Two factors contributed to the lower quality of the controls: the appearance and texture. The fresh samples were prepared from hand peeled fruit as done in the homes. Since the

TABLE 3.-Organoleptic evaluation of canned green bananas after three different storage times at 85-90 F (29.4-32.2 C) prepared for sereving as "guineos en escabeche"

\begin{tabular}{lcccccccccc}
\hline \multicolumn{1}{c}{ Item } & Control & $\begin{array}{c}\text { Canned } \\
\text { samples }\end{array}$ & Control & $\begin{array}{c}\text { Canned } \\
\text { samples }\end{array}$ & Control & $\begin{array}{c}\text { Canned } \\
\text { samples }\end{array}$ \\
\hline $\begin{array}{l}\text { Storage period-days } \\
\text { Organoleptic ratings }\end{array}$ & - & 47 & 33 & - & 159 & 146 & - & 321 & 308 \\
$\quad$ Appearance & 3.0 & 2.8 & 3.3 & 3.4 & 3.9 & 3.8 & 2.2 & 3.5 & 3.3 \\
$\quad$ Flavor & 3.3 & 2.8 & 3.3 & 3.9 & 3.8 & 3.0 & 2.9 & 2.8 & 2.8 \\
$\quad$ Off-flavors & 4.4 & 4.3 & 4.3 & 5.0 & 5.0 & 4.8 & 4.8 & 3.8 & 4.3 \\
Texture & 3.2 & 4.0 & 4.3 & 4.3 & 4.9 & 3.9 & 3.7 & 5.4 & 4.2 \\
$\quad$ Overall sample quality & 3.2 & 4.0 & 4.3 & 3.6 & 3.8 & 3.6 & 2.3 & 2.9 & 2.6 \\
\hline
\end{tabular}

enzyme system was not inactivated by heating (6) browning of the exposed tissue resulted, affecting the appearance. The canning process used to prepare these samples softened the fruit to a greater extent than boiling of the fresh bananas; therefore, the "escabeche" prepared from the canned fruit was found to be softer than that of the controls. In regard to the flavor and off-flavor ratings, no significant difference between the reference and test samples were observed.

During storage no significant changes were observed in appearance and flavor. Off-flavors increased slightly during storage, but did not impair quality. No changes in texture could be detected by the tasters. Table 4 shows an apparent decrease in sample quality after storage of the canned samples for 11 months. It should be noted, however, that the reference sample received an even lower rating, so it is possible that the lowering of the overall sample quality may have resulted from changes in the preparation of the "escabeche" rather than from changes in the canned product during storage. 
Of the different quality attributes, the color and the texture are the two more dependent on the quality of the fruit processed and on the processing methods used. Sánchez Nieva and Mercado (4) showed that inactivation of the enzyme system of bananas before peeling was the only reliable method to be used in controlling the browning of the fruit. Similarly, for canning, the enzyme system must be inactivated before peeling to avoid browning, which would adversely affect the appearance of the product. Sánchez Nieva and Mercado (8) indicated that in processing frozen bananas, uniformity of color was more important from the quality standpoint than the tone of yellow of the fruit. For canning, the same relationship holds: uniformity of the color seems to be more important than the color itself. Color uniformity may be assured by processing fruit of a uniform stage of development.

Sánchez Nieva et al. (8) showed that when the texture of the green bananas is measured with the shear press, shear press values decrease as

TABLE 4.-Effect of the pulp to peel ratio on the changes in the texture of the green bananas during canning and storage for 148 days at $85-90^{\circ} \mathrm{F}\left(29.4-32.2^{\circ} \mathrm{C}\right)$

\begin{tabular}{cccc}
\hline \multirow{2}{*}{ Pulp to peel ratio } & \multicolumn{2}{c}{ Shear press force } & \multirow{2}{*}{ Increase during storage } \\
\cline { 2 - 3 } & After canning & After storage & \\
\hline 1.0 & 34.5 & 78.0 & 43.5 \\
1.23 & 90.0 & 165.0 & 75.0 \\
1.33 & 112.5 & 196.5 & 84.0 \\
1.58 & 126.0 & 219.0 & 93.0 \\
\hline
\end{tabular}

pulp to peel ratios increase, indicating that the fruit softens with maturity. When green bananas are hot-water treated to inactivate the enzyme system and to facilitate peeling, the relationship between pulp to peel and texture is reversed: shear press values increase in direct relationship to the increase in pulp to peel ratios. These changes are shown in figure 1. When the hot-water peeled green bananas are canned, shear press value for texture increases with pulp to peel ratios, following the same trend as that observed for the hot-water treated fruit (see fig. 1).

Table 4 shows the relationship of pulp to peel ratios with shear press values with respect to changes in texture suffered by the canned bananas during storage at room temperature. After storage for a period of 148 days, the increase in shear press values is directly related to the pulp to peel ratio of the fruit processed. The more mature fruit with the higher pulp to peel ratio turned harder than the less developed. From the texture standpoint alone, for canning, processing fruit of low pulp to peel ratios will assure a more tender processed product.

Figure 2 shows the changes in texture suffered by green bananas during processing canning and storage. Hot-water peeling softens the fruit 
considerably, with a decrease in shear press values to almost $50 \%$ of that for the fresh hand-peeled fruit. Canning results in a further softening of the fruit. In a short interval after canning, shear press values increase rapidly and then level off, although an increase in texture values during storage continues, conforming to the equation $\mathrm{Y}=\mathrm{A}+\mathrm{B} \log _{\mathrm{e}} \mathrm{X}$. Since the major change in texture takes place during processing, the effects of

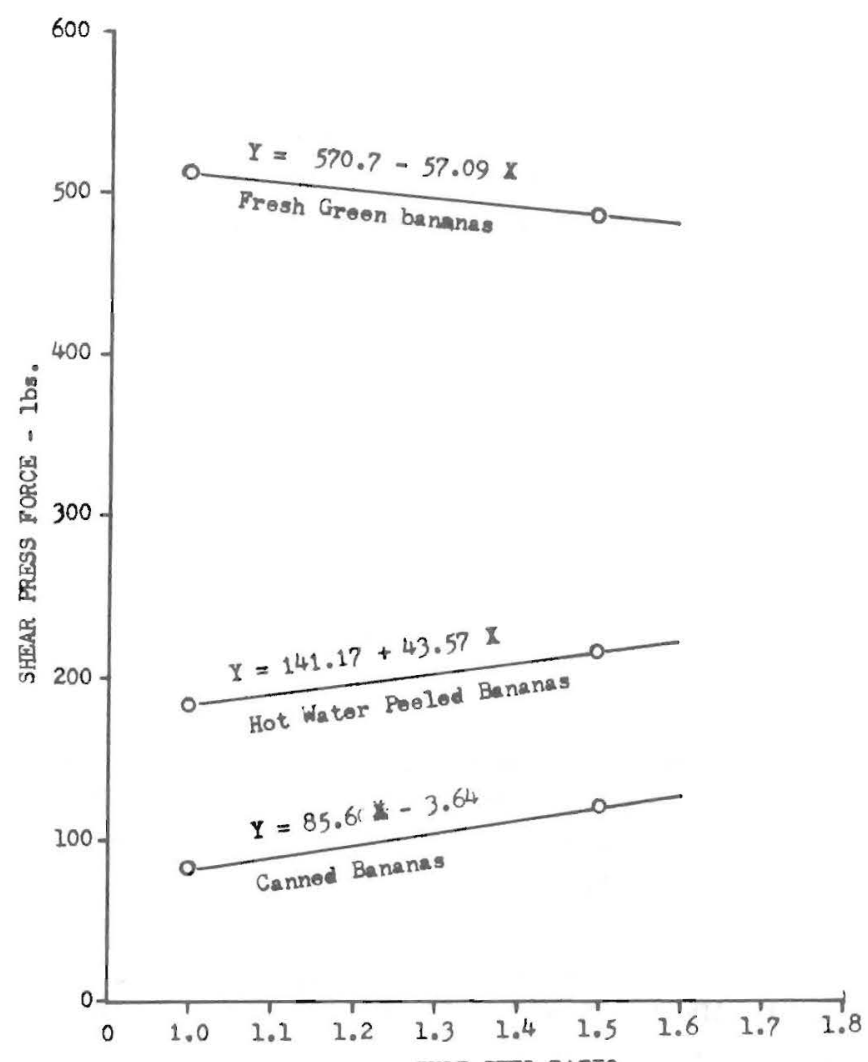

PULP: PERL RATIO

FIG. 1.-Changes in the texture of green bananas during peeling and canning as affected by the pulp to peel ratio.

several processing variables on the texture of the product were investigated.

Table 5 shows the effect of peeling and processing treatments on the texture of the canned product measured after different storage intervals. Peeling was done by heating the fruit in water at $200^{\circ} \mathrm{F}\left(93^{\circ} \mathrm{C}\right)$. Cans were processed in boiling water. The main effect of the treatments tested 
was that when the fruit was treated in water at $200^{\circ} \mathrm{F}\left(93^{\circ} \mathrm{C}\right)$ for 50 minutes there was a definite trend for shear press values to decrease as the time of processing in boiling water was increased from 30 to 50 minutes. The differences among the other treatments are smaller than the normal variations in texture values observed among readings from replicated samples, and do not show any definite trend. It should also be noted that the samples peeled and processed for 50 minutes show a definite trend for shear press values to decrease during storage. This

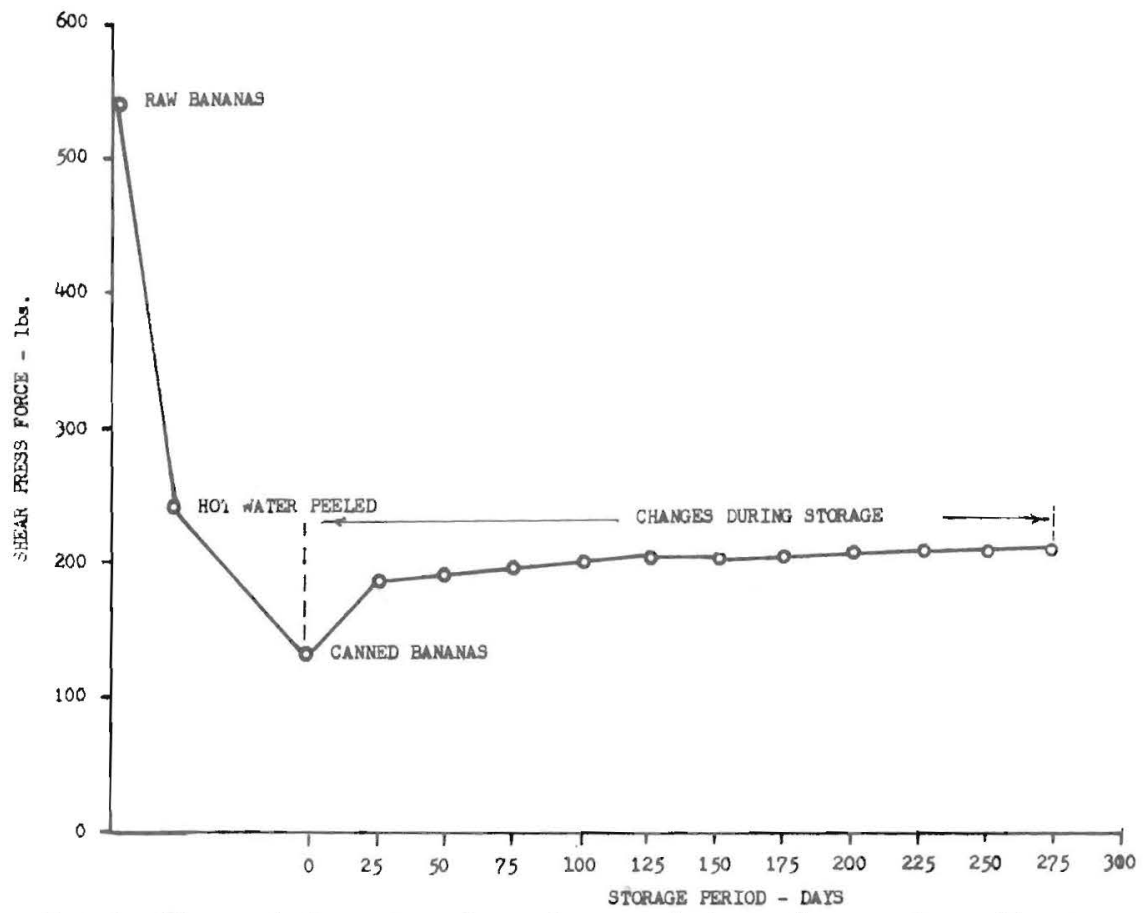

FIG. 2.-Changes in the texture of green bananas during peeling, canning and long term storage.

change in texture during storage is different from that shown in figure 3 , in which a gradual increase in texture was observed during storage.

Figure 3 shows the effect of the length of the boiling water processing when the bananas were treated or peeling for 15 minutes in boiling water. The lower shear press values and hence the softer texture resulted from a treatment corresponding to 50 minutes processing at $212^{\circ} \mathrm{F}\left(100^{\circ} \mathrm{C}\right)$. Texture values increased during storage, irrespective of the length of the processing treatment. 
TABLE 5.-Effect of peeling, processing and storage times on the texture of acidified canned green bananas

\begin{tabular}{cccc}
\hline \multirow{2}{*}{$\begin{array}{c}\text { Peeling time } \\
\text { at } 200^{\circ} \mathrm{F}\left(93^{\circ} \mathrm{C}\right)\end{array}$} & \multicolumn{3}{c}{ Processing time in boiling water-minutes } \\
\cline { 2 - 4 } & \multicolumn{3}{c}{ Shear press force } \\
\cline { 2 - 4 } Min & Storage time - 15 days \\
30 & 169.5 & 159.0 & 168.0 \\
40 & 169.5 & 159.0 & 160.0 \\
50 & 174.0 & 156.0 & 153.0 \\
& & Storage time-88 days & \\
30 & 159.0 & 151.5 & 142.5 \\
50 & 169.5 & 159.0 & 144.0 \\
50 & 163.5 & 150.0 & 129.0 \\
& & Storage time-190 days & \\
40 & 180.0 & 160.5 & 156.0 \\
50 & 156.0 & 157.5 & 153.0 \\
& 160.5 & 156.0 & 145.5 \\
\hline
\end{tabular}

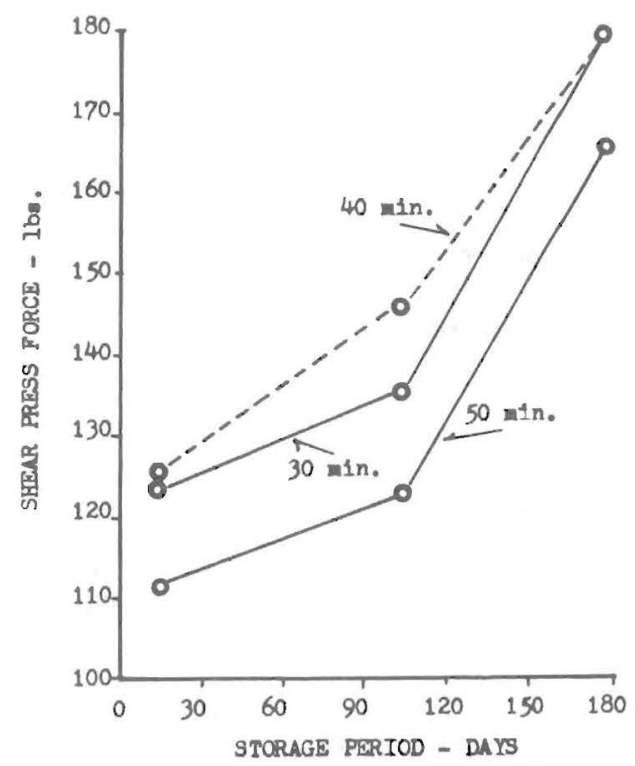

FIG. 3.-Effect of length of processing time at $212 \mathrm{~F}\left(100^{\mathrm{C}}\right)$ on the texture of green bananas peeled by treatment in boiling water for 15 minutes.

Figure 4 shows the effect of varying the length of the peeling treatment when processing in boiling water for 30 minutes. A control treated for 30 minutes in water at $200^{\circ} \mathrm{F}$ is included. In the following tabulation, shear 
press values for the peeled fruit before processing are given:

Peeling treatment

15 minutes at $212^{\circ} \mathrm{F}$

20 minutes at $212^{\circ} \mathrm{F}$

25 minutes at $212^{\circ} \mathrm{F}$

30 minutes at $212^{\circ} \mathrm{F}$

30 minutes at $212^{\circ} \mathrm{F}$
Shear Press values

273

175

169.5

129.0

213.0

Shear press values decreased in the peeled fruit as processing time was

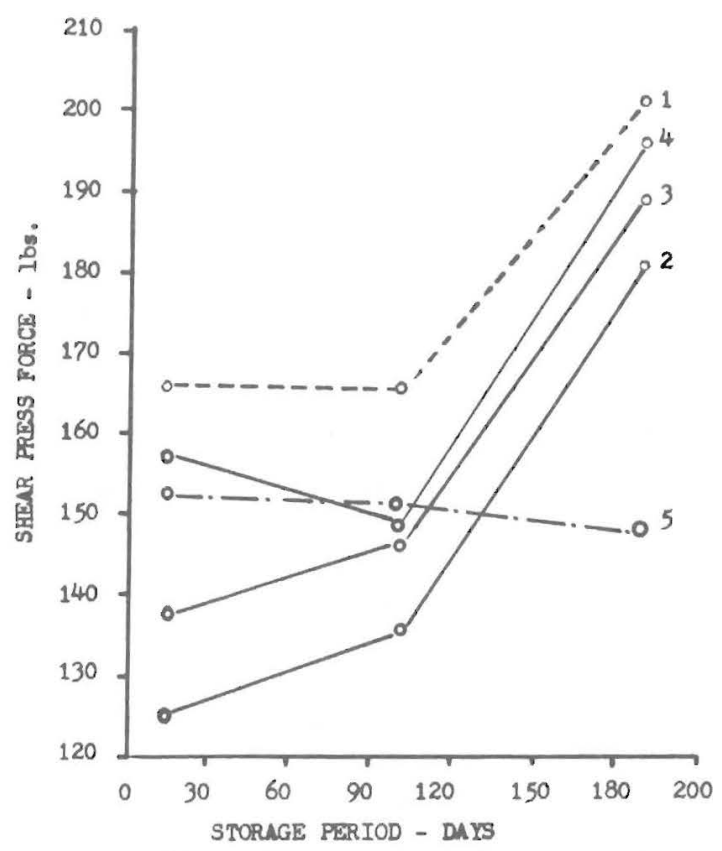

Curve No. Peoling time

$1 \quad 30=1$ n. at $200 \mathrm{~F}$

$2 \quad 15$ in. at $212 \mathbb{F}$

320 min. at $212 \mathbf{F}$

$4 \quad 25$ in. at $212 \%$

530 in. at $212 \mathbf{F}$

FIG. 4,-Effect of length of peeling treatment in boiling water on the texture of green bananas processed in the cans for 30 minutes in boiling water.

increased. Boiling the fruit for 30 minutes, which resulted in its complete cooking, lowered the shear press values the most. Figure 4 shows that in the canned product, shear press values increased in proportion to the time the fruit was boiled, with the exception of the samples boiled for 30 minutes. For the three storage periods studied, the same trend was observed; shear press values increased as peeling time increased from 15 to 25 minutes. It should be observed that the sample treated at $200^{\circ} \mathrm{F}$ $\left(93^{\circ} \mathrm{C}\right)$ for 30 minutes had a higher shear press value than the other 
samples. During storage, the shear press value increased quite appreciably in all samples, with the exception of the one boiled for 30 minutes, which remained almost constant, but decreasing slightly during storage.

The effect of several hot-water blanching treatments on the texture of hot-water peeled fruit was also investigated. Blanching at $195^{\circ} \mathrm{F}\left(90.5^{\circ}\right.$ C) from 2 to 10 minutes at a 2 -minute interval had no appreciable effect on the texture. Similar results were obtained from blanching for 5 minutes at $150,160,170$, and $180^{\circ} \mathrm{F}\left(66,71,77,82^{\circ} \mathrm{C}\right)$.

Tables 6 and 7 show the effects of the packing medium, the acidity

TABLE 6.-Effect of brine acidity and storage temperature on the texture of acidified green bananas canned in $2 \% \mathrm{w} / \mathrm{w} \mathrm{NaCl}$ brine

\begin{tabular}{|c|c|c|c|c|c|c|}
\hline \multirow{6}{*}{ Storage time } & \multicolumn{6}{|c|}{ Brine acidity } \\
\hline & \multicolumn{2}{|c|}{0.3} & \multicolumn{2}{|c|}{0.4} & \multicolumn{2}{|c|}{0.5} \\
\hline & \multicolumn{6}{|c|}{ Stabilization $\mathrm{pH}$} \\
\hline & \multicolumn{2}{|c|}{4.05} & \multicolumn{2}{|c|}{3.95} & \multicolumn{2}{|c|}{3.79} \\
\hline & \multicolumn{6}{|c|}{ Storage temperature } \\
\hline & $\begin{array}{c}85 \mathrm{~F} \\
29.4 \mathrm{C}\end{array}$ & $\begin{array}{l}45 \mathrm{~F} \\
7.2 \mathrm{C}\end{array}$ & $\begin{array}{r}85 \mathrm{~F} \\
29.4 \mathrm{C}\end{array}$ & $\begin{array}{l}45 \mathrm{~F} \\
7.2 \mathrm{C}\end{array}$ & $\begin{array}{c}85 \mathrm{~F} \\
29.4 \mathrm{C}\end{array}$ & $\begin{array}{l}45 \mathrm{~F} \\
7.2 \mathrm{C}\end{array}$ \\
\hline Days & \multicolumn{6}{|c|}{ Shear press values } \\
\hline 0 & 142.5 & 142.5 & 151.5 & 151.5 & 145.5 & 145.5 \\
\hline 14 & 160.9 & 200.0 & 178.0 & 210.9 & 159.9 & 222.0 \\
\hline 29 & 177.0 & 228.0 & 189.0 & 240.0 & 183.0 & 240.0 \\
\hline 61 & 181.2 & 244.2 & 201.0 & 252.0 & 186.0 & 258.0 \\
\hline 91 & 180.0 & 249.0 & 196.5 & 289.5 & 186.0 & 285.0 \\
\hline 126 & 213.9 & 300.0 & 一 & 309.0 & - & 313.8 \\
\hline 188 & - & 312.0 & - & 342 & - & 333.0 \\
\hline
\end{tabular}

TABLE 7.-Effect of acidity and storage temperature on the texture of acidified green bananas canned in salt $(\mathrm{NaCl})$ free citric acid solutions

\begin{tabular}{|c|c|c|c|c|c|c|}
\hline \multirow{6}{*}{ Storage time } & \multicolumn{6}{|c|}{ Acidity of citric acid solution } \\
\hline & \multicolumn{2}{|c|}{0.3} & \multicolumn{2}{|c|}{0.4} & \multicolumn{2}{|c|}{0.5} \\
\hline & \multicolumn{6}{|c|}{ Stabilization $\mathrm{pH}$} \\
\hline & \multicolumn{2}{|c|}{4.25} & \multicolumn{2}{|c|}{4.28} & \multicolumn{2}{|c|}{4.25} \\
\hline & \multicolumn{6}{|c|}{ Storage temperature } \\
\hline & $\begin{array}{c}85 \mathrm{~F} \\
29.4 \mathrm{C}\end{array}$ & $\begin{array}{l}45 \mathrm{~F} \\
7.2 \mathrm{C}\end{array}$ & $\begin{array}{c}85 \mathrm{~F} \\
29.4 \mathrm{C}\end{array}$ & $\begin{array}{l}45 \mathrm{~F} \\
7.2 \mathrm{C}\end{array}$ & $\begin{array}{c}85 \mathrm{~F} \\
29.4 \mathrm{C}\end{array}$ & $\begin{array}{l}45 \mathrm{~F} \\
7.2 \mathrm{C}\end{array}$ \\
\hline Days & \multicolumn{6}{|c|}{ Shear press force } \\
\hline 0 & 121.5 & 121.5 & 114.0 & 114.0 & 123.0 & 123.0 \\
\hline 12 & 163.8 & 198.6 & 153.0 & 180.6 & 181.8 & 231.6 \\
\hline 35 & 163.8 & 211.8 & 165.0 & 208.8 & 180.0 & 231.0 \\
\hline 60 & 174.0 & 231.0 & 178.5 & 238.5 & 205.5 & 238.5 \\
\hline 106 & 171.0 & 259.5 & 180.0 & 265.5 & 214.5 & 283.5 \\
\hline 138 & 201.1 & 273.0 & - & 283.5 & 一 & 312.0 \\
\hline 181 & 214.5 & 301.5 & 一 & 313.5 & 一 & 294.0 \\
\hline
\end{tabular}


and the storage temperature on the texture of canned green bananas.

Table 6 shows that when $2 \%$ brines acidified with citric acid to $0.3,0.4$ and $0.5 \mathrm{pH}$ were used as packing media, variations in the acidity of the brine had no effect on changes in texture during storage. However, storage at $45^{\circ} \mathrm{F}\left(7.2^{\circ} \mathrm{C}\right)$ had a pronounced effect on the texture: the fruit became much harder (higher shear press values than when stored at $85^{\circ} \mathrm{F}\left(29.4^{\circ}\right.$ C). It is a common occurrence for cooked green bananas products to become hard when stored in a refrigerator. In homes refrigerated storage of these products is avoided. Canned green bananas in this respect behaved similarly to home-prepared bananas.

Table 7 also shows that when a salt-free acid solution was used as packing medium, a change in acidity had no effect on the texture during storage. The storage temperture had the same effect as that observed for the samples packed in $2 \%$ brine. Storage at $45^{\circ} \mathrm{F}\left(7.2^{\circ} \mathrm{C}\right)$ resulted in a marked hardening of the product.

Comparison of the data in tables 6 and 7 shows that the use of salt at levels of $2 \%$ in the packing medium had no effect in texture when compared with a salt-free acid solution.

\section{RESUMEN}

Se estudió el comportamiento de guineos verdes enlatados durante 270 días de almacenamiento a temperatura ambiente $\left(85-90^{\circ} \mathrm{F}, 29-32^{\circ} \mathrm{C}\right)$. Se observó lo siguiente: ni el pH de estabilización ni el de la fruta, ni tampoco la acidez, cambiaron significativamente; el contenido de ácido ascórbico aumentó (esto se atribuye a la presencia de substancias reductoras que interfieren en la determinación de la vitamina); el color cambió ligeramente, ya que los valores Hunter $a$ y $b$ aumentaron durante el almacenamiento. Visualmente, se observó el desarrollo de una ligera coloración rosada. El color de la fruta enlatada dependió del estado de madurez de la fruta, aumentando los valores $a$ y $b$ al aumentar la proporción de pulpa a cáscara segun desarrollaba la fruta.

Para evaluar los cambios organolépticos durante el almacenamiento, se prepararon guineos verdes elatados en escabeche. Este plato se prepara con los guineos verdes hervidos, los que se marinan luego en una salsa de aceite de oliva, vinagre, cebollas y condimentos. Para cada cata se preparó además un escabeche con guineos frescos para compararlos con los enlatados. En tres catas a intervalos regulares durante el período de almacenamiento, el escabeche preparado con guineos elatados se juzgó superior en calidad al preparado con guineos frescos. Tampoco tuvieron lugar cambios significativos en el sabor, el color y la textura del producto enlatado.

Durante el almacenamiento se observó un endurecimiento de los guineos, según se determinó del aumento en los valores de textura registrados por la prensa de la Food Technology Corporation ("shear press"). 
Estos valores variaron de acuerdo con la ecuación $\mathrm{Y}=\mathrm{A}+\mathrm{B} \log \mathrm{X}$. Aparentemente, los cambios más drásticos en la textura tienen lugar durante la elaboración y enlatado de los guineos. Al calentarlos en agua por 30 minutos a $200^{\circ} \mathrm{F}\left(93^{\circ} \mathrm{C}\right)$ para inactivar el sistema enzimático y facilitar el pelarlos, los guineos se ablandan considerablemente. Si se calientan por más tiempo del indicado, se ablandan aún más. Cuando los guineos se trataron con agua a $200^{\circ} \mathrm{F}\left(93^{\circ} \mathrm{C}\right)$ por 50 minutos se esterilizaron en agua hirviendo por otros 50 minutos después de enlatados se observó una tendencia bien marcada en la fruta a ablandarse durante el almacenamiento a temperatura ambiente.

Cuando la fruta verde se hirvió por 15, 20 y 25 minutos para inactivar el sistema enzimático y petarlos, la dureza de la fruta enlatada aumentó durante el almacenamiento en relación directa con la duración del tratamiento con agua hirviendo. Sin embargo, cuando la fruta se hirvió por un período de 30 minutos la textura no cambió significativamente durante el almacenamiento.

Variaciones en la acidez de la salmuera o el uso de sal no afectaron la textura de la fruta. El almacenamiento del producto a una tempertura de $45^{\circ} \mathrm{F}\left(7.2^{\circ} \mathrm{C}\right)$ endureció la fruta enlatada marcadamente.

\section{LITERATURE CITED}

1. Anon., 1979. Acidified food and low acid canned foods in hermetically sealed containers, Fed. Reg. 44: 16204-238.

2. Moyer, J. C. and Holgate, K. C., 1948. Determination of alcohol insoluble solids and sugar content of vegetables, Anal. Chem. 20 (5): 472-74.

3. Official Methods of Analysis of the Association of Official Agricultural Chemists, 12th ed, Washington, D. C. 1975.

4. Ranganna, S. and Parpia, H. A. B., 1974. Pink discoloration in canned bananas and field beans. I. Processing factors contributing to discoloration, Lebensm-Wiss. + Technol. 7 (2) 101-10.

5. — II. Chemical changes in leucoanthocyanidins during processing, Lebensm-Wiss + Technol. 7 (2): 111-19.

6. Sánchez Nieva, F. and Mercado, M., 1978. Control of enzymatic browning in green bananas for freezing, J. Agric. Univ. P. R. 62 (3): 232-40.

7. — and — 1978. Effect of peeling method and sulfitation on the shelf life of frozen bananas, J. Agric. Univ. P. R. 62 (3): 241-48.

8. _ - - and Bueso, C., 1980. Effect of stage of development at harvest on the texture, flavor, quality and yields of frozen green bananas, J. Agric. Univ. P. R. 64 (3): 27582.

9. — and — 1980. Relationship between the stage of development of the fruit harvested and the color of frozen green bananas, J. Agric. Univ. P. R. 64 (3): 28393.

10. — and — 1983. Studies on the canning of green bananas. I. Processing factors affecting the acidification of hot water peeled fruit, J. Agric. Univ. P. R. 67 (4): $339-55$.

11. — Bueso C. and Mercado M., 1983. Studies on the canning of green bananas. II. Internal corrosion of plain tin containers by the acidified green bananas. J. Agric. Univ. 67 (4): 356-65. 